(Natural History), the libraries of the Zoological Society of London, of the Commonwealth Institute of Entomology, the Linnean Society of London, the Royal Entomological Society and the Horniman Museum and Library, though there is a brief note on other sources also, such as the holdings of the Science Museum Library and the Patent Office Library. The British Museum (Natural History) Library, which probably contains the largest collection of zoological books and periodicals in Britain, is described in some detail by Mr. Townsend and that of the Zoological Society by Mr. Stratton. The authors are to be congratulated on a most useful guide to sources of zoological literature, the value of which is enhanced both by the inclusion of references to other accounts of particular libraries and to the main bibliographies of zoology. There is an index to persons, institutions and serials.

\section{Christian Faith and the Freedom of Science}

Dr. R. Hooykaas, professor of the history of science at the Free University, Amsterdam, is the author of a recent pamphlet on "Christian Faith and the Freedom of Science" (Philosophia Libera. Pp. 24. London: The Tyndale Press, 1957. Published for the Research Scientists' Christian Fellowship. 1s. 6d.), in which he points out that science is stifled whenever men cherish preconceived ideas which they refuse to submit to test, whether under totalitarianism, secular or clerical, or whenever a well-meaning piety exalts secondary standards of authority to a place that belongs only to God. Prof. Hooykaas contends that Scripture, rightly approached, liberates the mind from all these constraints. Reviewing the several threats to the freedom of science, he cites Calvin as an example of a man made free from traditional beliefs and unhampered by an elaborate theory of inspiration. He argues that confidence in the possibilities of science and in the freedom of thought, as well as self-restriction in theorizing and obedience to the dictates of Nature, are the necessary consequences of a truly liberal religion, and illustrates his argument by a brief historical survey of relations between science and religion in the Middle Ages, in the Reformation period and in the seventeenth century. The Puritan scientists of the seventeenth century regarded science as an ally of true religion, and Prof. Hooykaas points out that the educational ideals of the Enlightenment and those of the English Puritans were almost the same, the Enlightenment being considered as a secularized puritanism. The spirit of the Reformation and the spirit of science have much in common.

\section{Electronic Image Devices in Microscopy}

REPORTs on the use of electronic image converters, television cameras and flying-spot scanning systems in microscopy have appeared from time to time; but it cannot be said that these methods have been responsible for any spectacular advances. Their theoretical possibilities are considerable, but as vet the practical results have been disappointing. Despite the high cost and complexity of the apparatus, electronic 'noise' and other imperfections usually reduce the image quality to below that obtainable by simple visual or photographic methods. A very attractive feature is the possibility of image intensification, that is, the ability to present a bright picture on a sereen even though the object itself may be very weakly illuminated. This is most important in ultra-violet microscopy, since ultra-violet light damages living cells. A remarkable ultra-violet colourtranslating television microscopy has recently been developed at the Rockefeller Institute, New York, by V. K. Zworykin, F. L. Hatke and C. Berkley. The instrument recalls the earlier photographic one described by E. H. Land and his collaborators (Science, 109, 371; 1949), in which the specimen was illuminated in turn by three monochromatic bands of ultra-violet light, and three photographic negatives were made. After processing at high speed in a special machine, these negatives were projected simultaneously through red, green and blue filters on to a viewing screen. In this way differences in ultra-violet spectral absorption were 'translated' into differences in visible colour. It was claimed that by a proper selection of illuminating wave-lengths colour differences could be related to variations in chemical composition, particularly with regard to proteins and nucleic acids. The new system eliminates photography by employing a closed-circuit colour television receiver, so that its action is virtually instantaneous and it is possible to view cells in motion. No results of any biological importance have yet been reported with the original colour-translating microscope, and it remains to be seen whether the new instrument will turn out to be simply another brilliant technological achievement. Nevertheless, there is little doubt that the next generation of microscopists will use electronic devices almost as freely as photography is used to-day, and this pioneer work must be followed with cautious and sympathetic interest.

\section{Geological Resources of Britain}

AT a meeting of the Parliamentary and Scientific Committee on May 14, a discussion on British geological resources was opened by Sir William Pugh, director of the Geological Survey and Museum, who described the work of the Geological Survey of Great Britain in relation to supplies of coal, iron ore and water. He stressed the dependence of development and exploitation of these and other natural resources on the up-to-date, large-scale geological maps and memoirs which it is the primary function of the Geological Survey to provide. Mr. P. T. Cox, of the British Petroleum Co., Ltd., who spoke next, dealt with the oil resources of Britain, and particularly the results of recent prospecting, which, at present, is concentrated principally in the Eakring area of Nottinghamshire, where the ultimate production of some 10 million tons is probably the limit. Mr. H. E. Collins, of the National Coal Board, paid tribute to the help of the Geological Survey in the Board's drilling programme. This programme had already provided resources estimated at more than 4,000 million tons through the construction of fifteen new collieries and the reconstruction of some 200 existing collieries. Sir Arnold Waters dealt with problems of water supply, ironstone, and sand and gravel supplies, pointing out that the demand for sand and gravel had already considerably exceeded the expectations of the Advisory Committee. In the discussion that followed, Mr. Collins said that there are sufficient proved coal resources for current development, and further proving would continue around the fringes of coalfields now being exploited. Sir Arnold Waters said that improved land drainage and the great impermeable urban areas were affecting the average rate at. which water reaches the under- 